\title{
A Market Segmentation Approach to Daily Newspaper Audience Studies
}

\author{
Study of Southwestern metro area \\ indicates newspaper audience is not \\ monolithic but rather a collection \\ of numerous subsegments.
}

- While the other media have been attempting to provide the advertiser with more specific data concerning the size and composition of their audiences by breaking down the audience into both demographic and psychographic segments, the daily newspaper has tended to ignore such distinctions and to continue to report audience information only in terms of circulation. The president of the Television Bureau of Advertising was quoted recently as saying, "Television is very research minded. Newspapers, since their inception, have been selling on circulation alone and they don't like to change. We are delighted they are doing this."I

While circulation continues to climb in most communities, new evidence indicates that newspaper penetration into these communities has, in fact, been declining. This evidence has led media managers in many of the major metropolitan areas to begin to seek more information about their audience-and potential audience - and to begin to demand research which will provide them with better insights into the wants, needs and desires of these potential audience members.

\footnotetext{
'Anon., "TrB's Roger Rice Cites Key Newspaper Weakness," Edisor \& Publisher. May 1, 1976. pp. 30-33.

'Yankelovich, Skelly and White. Inc., Young People and Newspapers: An Exploratory Siudy, prepared for Harte-Hanks Newspapers, Inc., May 1976.

'Emest F. Larkin, Gerald L. Grotta, and Philip Stout, "The 21-34 Year Old Market and the Daily Newspaper." American Newspaper Publishers Association Research Report, April, 1977.
}

The data on which this report is based has been gathered under the sponsorship of the News Research Center of the American Newspaper Publishers Association. While the study covered a much broader range of questions concerning the audience of the daily newspaper, this report will deal with information relating to market segmentation of that audience based on relevant age groups. While this by no means exhausts the possibilities for meaningful analysis of this data, it should provide valuable insights into the significant differences between age groups and thus provide information of value to the advertiser and the media manager alike.

\section{The Problem}

The study was designed to determine whether differences in attitude toward, and utilization of, the daily newspaper could be discovered within a random sample of individuals selected from a major southwestern metro area, using age as the criterion variable.

Age was selected in this first analysis of the data because of the growing emphasis being placed on age as an important variable in audience segmentation. Studies such as the Yankelovich, Skelly and White study ${ }^{2}$ and the study recently completed for the ANPA ${ }^{3}$ both have called attention to one age group within this larger market.

While comparisons such as these are important to a better understanding of this single segment, more information is

\footnotetext{
- Ernest F. Larkin is associate professor of journalism at the University of Oklahoma. Gerald L. Grotta is vice president of RMH Research Inc. Ridgewood, N J
} 


\section{TABLE 1}

Distribution of Age in Sample, by Percent

$\begin{array}{llll}\text { Age Group } & \text { Male } & \text { Female } & \text { Total } \\ 19-24 & 27.9 \% & 70.5 \% & 12.7 \% \\ 25-34 & 28.2 & 71.8 & 25.8 \\ 35-44 & 42.3 & 57.7 & 14.8 \\ 45-54 & 29.2 & 70.8 & 13.5 \\ 55-64 & 44.2 & 55.8 & 17.9 \\ 65+ & 35.1 & 64.9 & 15.4 \\ \text { TOTALS } & \mathrm{N}=166 & \mathrm{~N}=315 & \mathrm{~N}=481\end{array}$

needed which will enable the media manager and the advertiser to compare age groups to see if trends in perception and utilization of the mass media can be detected.

\section{Methodology}

The first step in this study was to conduct a series of focus group interviews with a purposively selected sample of individuals from the metro area in which this study was to be conducted. These individuals were selected so as to provide respondents from the major segments of the population, representing as many different demographic and psychographic characteristics as possible. Fifteen individuals were interviewed-seven males and eight females. The interviews were conducted in two separate sessions in the facilities of an independent research firm. Both sessions were recorded on video and audio tape.

Based on the information gained from analysis of these in-depth interviews, a structured questionnaire was developed. This questionnaire was designed to gain maximum information about attitudes toward, and stated use of, the major mass media-especially newspapers. After extensive pretesting and revision, the questionnaire was administered to 500 subjects randomly selected from the population of a major southwestern metropolitan area.

This second phase of the study was conducted by an independent research firm. Subjects were personally interviewed by trained, paid interviewers. The questionnaire was administered as part of a larger study of consumer behavior and media usage.
From the 500 individuals interviewed during the summer and fall of 1976, 481 usable questionnaires were returned$34.5 \%$ from men and $65.5 \%$ from women. Table 1 shows the age distribution.

Two broad categories of questions were included in the questionnaire: 1) media perception questions designed to determine the opinions and attitudes held by respondents toward the mass media, and 2) newspaper content questions designed to determine what respondents look for in the newspaper.

\section{Findings}

Subjects were asked to rank 24 statements relating to their perception of the performance of the mass media. Table 2 shows the ranking received by each of the statements across each of six age categories.

19-24 Year Olds. This group tends to turn to television for both its news and entertainment. They generally like what they see on television and are not concerned that television news is too "brief and sketchy." On the other hand, while these respondents feel that the newspaper does a good job of covering the news they are interested in, they also suspect that the newspaper tends to "cover up" stories which they feel should be reported; that they are "slanted and do not present both sides of controversial issues," and that they are "controlled" by local advertisers. While they feel they are "getting their money's worth" from the newspaper, they are not willing to pay more for it.

Perhaps the two most revealing statements are those which deal with the advertising. This group strongly disagrees with the idea that "advertising in the local newspaper is of little value and irritating," but also strongly disagrees with the statement that "if TV stations would cut out all advertising I would find them less useful." This, and information to be discussed later, tends to indicate a strong reliance on the part of this age group on the newspaper as a source of shopping information.

25-34 Year Olds. While this group also 
TABLE 2

Ranking of Media Perception Statements by Age Groups

Statement

$19.24 \quad 25-34 \quad 35-44 \quad 45-54 \quad 55-65 \quad 65+$

I. I think the newspaper I read does a good job of covering news that I am interested in

2. I think newspapers are slanted and do not present both sides of controversial issues

3. Newspapers often "cover up" stories which I believe should be reported

4. If newspapers would cut out all advertising

I would find them less useful

$19.24-25-34,35-44$ 45-54 $55-65$ 65t

5. I think newspapers adequately serve the needs of the various minorities in this community

$\begin{array}{llllll}2 & 4 & 3 & 1 & 1 & 1\end{array}$

I think news magazines are too opinionated

7. Television often "covers up" stories which 1 believe should be reported

8. I find advertising on television of little value and irritating

$\begin{array}{llllll}6 & 1 & 4 & 3 & 8 & 8\end{array}$

9. Local advertisers have a great deal of control over what is, and what is not, reported in newspapers

$\begin{array}{llllll}5 & 10 & 16 & 12 & 5 & 5\end{array}$

10. Local advertisers have a great deal of control over what is, and what is not, reported on television news

$\begin{array}{llllll}11 & 12 & 17 & 4 & 10 & 3\end{array}$

11. I would rather watch an entertaining program on television than a news show

12. I generally like what I see on TV 1

13. I read magazines more for pleasure than for information

$\begin{array}{llllll}10 & 9 & 6 & 5 & 4 & 2\end{array}$

$\begin{array}{llllll}12 & 5 & 5 & 6 & 6 & 4\end{array}$

$\begin{array}{llllll}7 & 7 & 10 & 12 & 5 & 11\end{array}$

$\begin{array}{llllll}14 & 11 & 2 & 9 & 11 & 7\end{array}$

14. I tend to agree with the editorial views in the newspaper I read

15. I think the owners of television stations are just interested in making money and don't really care about the people

16. The newspaper I read tends to be more liberal than my own political views

$\begin{array}{llllll}16 & 17 & 14 & 15 & 13 & 16\end{array}$

17. I think newspapers leave out too much detail in their stories

$\begin{array}{llllll}17 & 16 & 18 & 13 & 19 & 18\end{array}$

18. If TV stations would cut out all advertising I would find them less useful

$\begin{array}{llllll}24 & 19 & 15 & 18 & 14 & 14\end{array}$

19 I don't think I get my money's worth from the newspaper I read 
20. I think the people who run the daily newspaper are out of touch with the people of this community 18

21. I think television news is too brief and sketchy 18 15

22

2. I would be willing to pay more for newspapers if they had more items that interested me

23. I prefer the comics and feature stories in the newspaper to the regular news items

$\begin{array}{llllll}15 & 22 & 23 & 24 & 24 & 24 \\ 23 & 24 & 24 & 21 & 20 & 20\end{array}$

24. I find advertising in the newspaper to be of little value and irritating

turns to television for its news and entertainment, it is not as strongly dependent upon television as its source of information. However, this group seems to be much more concerned with the perceived shortcomings of the newspaper than does the younger group. These respondents for example, are more concerned over "slanted" news and "cover ups" by the newspaper, and are less apt to look at only the comics and feature stories in the paper.

Again it is the advertising related statements which seem to be the most revealing for this age group. These respondents tend to perceive newspaper advertising as more useful than television advertising. For example, they strongly agree with the statement "if newspapers would cut out all advertising I would find them less useful," while strongly disagreeing with a similar statement about television advertising. They also disagreed strongly with the statement "I find advertising in the newspaper to be of little value and irritating."

35-44 Year Olds. Of all the age groups studied, this one is by far the most concerned with the advertising content of the media. For example, these respondents strongly agree that "if newspapers would cut out all advertising I would find them less useful," and just as strongly disagree with the statement "I find advertising in the newspaper to be of little value and irritating." Finally, they strongly agree with the statement "I find advertising on television to be of little value and irritating."

While this group leans more toward the newspaper for both news and for advertising, it is still concerned with the perceived problems of newspaper coverage. These respondents agree that the newspaper does a good job of covering news in which they are interested, but also agree that the newspaper is "slanted" in covering controversial issues.

45-54, 55-64 and Over 65 Age Groups. The remaining three age groups hold very similar views regarding the performance of the media. In general they are much more satisfied with the performance of the newspaper and much less dependent upon television for their news than the younger age groups.

All three of these groups feel that "the newspaper I read does a good job of covering news that I am interested in," and that "newspaper adequately serve the needs of the various minorities' in this community." They are still concerned over "slanted" news in their newspaper and over the amount of "local advertiser control," which they perceive to exist.

These groups also are less concerned with the advertising content of the newspaper and of television than are the younger groups. But they all agree that newspaper advertising is not irritating or of little value to them.

Media Content. Subjects in this study were asked to rank 34 statements regarding the type of content they would most like to see in their daily newspaper. Ta- 
TABLE 3

\section{Rank of Media Content Statements by Age Groups}

\section{Statement}

1. Consumer information (how to shop)

2. Stories about local events

3. Advertisements about products or events of special interest to me

4. Stories about national events

5. Stories about schools and education

6. How-to-do-it articles

7. Detailed background information on complex events

8. Gardening information

9. Recipes and cooking hints

10. Entertaining "feature" stories

11. Photographs

12. Stories about churches and religion

13. Letters to the editor from readers

14. Entertainment advertising (movies, etc.)

15. Clothing advertising

16. Restaurant guides

17. Editorials

18. Stories about camping, picnicking, etc.

19. Advice columns (Ann Landers, etc.)

20. Grocery advertising

21. Stories about clothing and fashions

22. Political news

23. Movie reviews and schedules

24. Stories about spectator spoits

25. Classified advertising

26. Comics (funny papers)

27. Stories about participant sports (golf, etc.)

28. Crime news

29. Furniture and appliance advertising

30. Stories about hunting and fishing

31. Automobile advertising
19-24 25-34 35-44 45-54 55-64 65+

$\begin{array}{rrrrrr}3 & 1 & 1 & 1 & 2 & 5 \\ 5 & 9 & 2 & 3 & 1 & 1 \\ 1 & 4 & 3 & 8 & 5 & 6 \\ 12 & 5 & 6 & 2 & 3 & 2 \\ 11 & 3 & 5 & 4 & 4 & 4 \\ 7 & 2 & 7 & 7 & 6 & 14 \\ 8 & 7 & 4 & 5 & 9 & 11 \\ 15 & 10 & 9 & 6 & 8 & 7 \\ 10 & 13 & 10 & 9 & 10 & 8 \\ 6 & 6 & 8 & 13 & 12 & 15 \\ 9 & 8 & 11 & 11 & 18 & 19 \\ 28 & 18 & 13 & 12 & 7 & 3 \\ 21 & 14 & 12 & 14 & 11 & 9\end{array}$

$\begin{array}{llllll}2 & 11 & 20 & 18 & 20 & 22\end{array}$

$\begin{array}{llllll}13 & 16 & 18 & 17 & 15 & 16\end{array}$

$\begin{array}{llllll}14 & 15 & 14 & 15 & 21 & 20\end{array}$

$\begin{array}{llllll}26 & 24 & 17 & 10 & 14 & 12\end{array}$

$\begin{array}{llllll}19 & 19 & 16 & 20 & 13 & 25\end{array}$

$\begin{array}{llllll}27 & 26 & 24 & 16 & 16 & 10\end{array}$

$\begin{array}{llllll}16 & 17 & 28 & 19 & 22 & 13\end{array}$

$\begin{array}{llllll}17 & 20 & 29 & 21 & 19 & 17\end{array}$

$\begin{array}{llllll}20 & 23 & 15 & 25 & 22 & 18\end{array}$

$\begin{array}{llllll}4 & 12 & 27 & 27 & 30 & 32\end{array}$

$\begin{array}{llllll}33 & 30 & 19 & 22 & 17 & 21\end{array}$

$\begin{array}{llllll}23 & 21 & 21 & 24 & 26 & 30\end{array}$

$\begin{array}{llllll}22 & 27 & 22 & 28 & 25 & 23\end{array}$

$\begin{array}{llllll}25 & 29 & 23 & 23 & 27 & 28\end{array}$

$\begin{array}{llllll}18 & 22 & 31 & 31 & 31 & 26\end{array}$

$\begin{array}{llllll}24 & 28 & 26 & 29 & 29 & 24\end{array}$

$\begin{array}{llllll}32 & 32 & 25 & 26 & 24 & 29\end{array}$

$\begin{array}{llllll}29 & 31 & 30 & 30 & 28 & 27\end{array}$ 
32. Engagements, weddings and "society" news

$\begin{array}{llllll}30 & 33 & 34 & 32 & 33 & 31 \\ 34 & 25 & 33 & 34 & 34 & 34 \\ 31 & 34 & 32 & 33 & 32 & 33\end{array}$

33. Stories about alternative life styles organizations

local newspaper. They are less inter-

ble 3 shows the ranking for each statement across the the six age groups.

19-24 Year Olds. This group wants ads and stories about products and events of interest to them; entertainment advertising such as movies, plays, etc., and movie review: and schedules. They also seek out the entertaining feature stories in the newspaper and the "how-to-do-it articles."

This group is least interested in stories about spectator sports, hunting and fishing, club news and "society" news.

25-34 Year Olds. These individuals are much more interested in information which will help them shop wisely and make the best possible use of the time and money at their disposal. They are concerned about schools and look for stories about national events in the newspaper with much more interest than the younger individuals.

They are least interested in stories about clubs and organizations, "society" news, stories about hunting and fishing and about spectator sports. Nor are they too concerned about automotive or furniture and appliance advertising.

35-44 Year Olds. They also want information which will help them in their dayto-day living. Consumer information, ads about products and events of special interest to them, stories about schools and education and stories about both national and local events are high on their list.

They are least interested in "society" news, stories about alternative lifestyles and stories about clubs and organizations. Nor are they very interested in grocery ads, clothing articles and ads for automobiles.

45-54 Year Olds. The only difference in their content preference is the desire for a greater emphasis on gardening information and recipes and cooking hints and a desire for more editorials in the ested in political news, comics and crime news than the younger groups.

55-64 Year Olds. One major difference in the type of content of greatest interest to this group is the emphasis on local events over all other types of stories. This group is also more apt to seek out information about churches and religion than the younger age groups.

These respondents are least interested in stories about alternative lifestyles, "society" news and stories about clubs and organizations. In general, however, they are very similar to the three preceding groups.

Over 65 Year Olds. Of all the age groups included in this study the very young and the very old have the most divergent tastes as far as newspaper content is concerned.

This age group looks for local and narional news stories first and then for stories about churches and religion, and schools and education. It is much less interested in consumer information than any of the other age groups and more interested in gardening information, recipes and cooking hints, advice columns and letters to the editor.

\section{Summary and Conclusions}

Using age as a basis for discovering differences between various subsegments of the newspaper audience leads to several important findings.

First it becomes more evident that the younger individuals (especially those between 19-24 years of age) have considerably different attitudes toward newspapers than do the older individuals in this study. These young consumers tend to turn more to television for both their information and entertainment. They also tend to be suspicous of newspapers because of perceived bias in the treatment 
of the news content and the perceived tendency to "cover up" stories which they feel should be reported.

The one reason why the members of this age group use the newspaper is for the advertising content. They feel newspaper advertising is useful and not nearly as irritating as television advertising. They say they would find the newspaper less useful if the advertisements were left out-but the same is not true for television.

The type of content this group is most interested in seeing in the daily newspaper is predominantly entertainmentoriented news and advertising. They are also very interested in information which will help them cope with the problems of daily living such as how-to-do-it articles, consumer information dealing with how to shop for the best buys and detailed background stories on complex events.

By comparison the older age groups tend to have a much more positive attitude toward the newspaper and to turn to it for more and more of their information as we move from younger to older groups. Members of the 25-34 year old group still tend to turn to television for their entertainment and information. but not as much as younger individuals. This age group also harbors many of the same doubts about the "objectivity" of the newspaper as does the younger group. However, like the younger individuals, this group feels that the newspaper is the best source of consumer information in both its news and advertising content and would find the newspaper much less useful if it left out all advertising.

This age group wants information which will help solve problems of daily living. These respondents want more consumer information; how-to-do-it articles; gardening information and stories about schools and education; local and national events, and detailed background information on complex issues.

The 25-34 year olds and 35-44 year olds are very similar in their attitudes toward the newspaper, but the advertising content becomes even more important for the older group. These respondents are much more in search of advertising content in the newspaper, and much less tolerant of television advertising. They are also less critical of the performance of the local newspaper.

The 45-54 year old group is less dependent on the advertising content of the newspaper and is also much less critical of its performance than any of the younger age groups. These respondents are concerned about the bias and slanted treatment of controversial issues, but feel that the newspaper is still doing a good job of covering the news they want to read. The same is true of the 55-64 year olds.

Of all of the age groups, those over 65 are the least critical of the newspaper. These respondents are apparently satisfied with the way it handles the news, and while they feel the local advertiser may have too much say in what goes into the paper this does not prevent them from accepting it as a reliable source of information. The older age groups are the least interested in consumer information.

What does all of this mean to the advertiser or to the media manager? To the advertiser it should indicate that if he is still viewing the newspaper through the traditional "monolithic" perspective, he may need to take a fresh look at the newspaper and the audience it is reaching. He may also wish to consider the amount and type of information about audience size and composition the daily newspaper provides for him and determine whether or not it is sufficiently useful in evaluating the place of the daily newspaper in his media schedule.

To the media manager this may mean that it is time to take a long, hard look at the content and format of the newnpaper product and attempt to determine how he can do a better job of appealing to the various segments of his market. A rview of both editorial and advertising content, as well as the overall format of the newspaper may be needed in order to find ways to make it more attractive to each of the various segments.

(Please turn to page 133) 
craft-related magazines and pamphlets and women's and home magazines-which usually contain content related to crafts and hobbies. This suggests that these kinds of print media have a high degree of what Coleman has called "bibliotherapeutic" utility. ${ }^{6}$ In other words, they seem to be saved to facilitate craft work by the patients - an important therapeutic and recreational individual and group activity.

The results of the observations related to mass media use could very easily lead one to suggest that most mass media are not important to the mental patient. However, looking at the results for the observations of the additional lounge activities helps to put the lack of a variety of mass-media consumption in perspective. If the patients were not reading

- James C. Coleman. Abnormal Psychology and Modern Life 4th ed. (Glenview, Ill.: Scott, Foresman and Company. 1972). magazines, newspapers or books or listening to the radio, they were not doing much else in the lounges either-except watching television.

This documentation of the dominance of TV viewing and the lack of additional media use suggests there are two areas where cooperative research between mass communication investigators and mental health officials might prove fruitful. First, it seems clear that they should investigate the possibility, as suggested by Rubinstein $e t$ al., that television viewing can be incorporated into therapeutic programs. Second, they can work together to investigate whether it would be beneficial to try and develop ways that other mass media (particularly the print media) could become more important ingredients in the total media diet of the institutionalized mental patient.

\section{DAILY NEWSPAPER AUDIENCE STUDIES (Continued from page 37)}

The media manager may also want to give consideration to a better means of promoting his newspaper product to the various segments of his audience. It may be necessary for him to call the attention of each specific segment to the amount and type of information he provides through his newspaper which fulfills their specific wants, needs and desires. While it is possible to generalize some of the findings from this study to all newspapers, there is a danger of overdoing it. Each newspaper market will undoubtedly present its own specific problems which the media manager in that market must be aware of.

\section{KIPC-FM PUEBLO INDIAN RADIO (Continued from page 101)}

of its audience and the lack of altemative media. KSHI-FM Zuni radio (in western New Mexico), scheduled to begin broadcasting in June of 1978 , should by all indications succeed, as its situation closely resembles that of the Navajo station. KIPC-FM Pueblo radio failed for the opposite reasons: its target audience enjoyed a greater degree of cultural integration and media competition.
Hindsight strongly suggests that the All Indian Pueblo Council could have met their objectives by purchasing a block of time on a daily basis from an existing AM station with sufficient power to reach the Pueblos. This would have met most every need except that of ownership. But considering the temper of the times, the state of Indian consciousness, that is perhaps the one need least negotiable. 